\title{
PENGARUH UMUR PERUSAHAAN, INFLASI, DAN SUKU BUNGA TERHADAP UNDERPRICING \\ (Pada Perusahaan Property dan Real Estate yang Melakukan IPO Di Bursa Efek Indonesia Periode 2012 - 2019)
}

\author{
Tenry Iryma Maygista \\ (Program Studi Manajemen, Fakultas Ekonomika dan Bisnis Universitas Kanjuruhan, Malang) \\ e-mail: tenrymaygista54@gmail.com \\ Rita Indah Mustikowati \\ Riril Mardiana Firdaus \\ (Program Studi Manajemen, Fakultas Ekonomika dan Bisnis, Universitas Kanjuruhan, Malang)
}

\begin{abstract}
ABSTRAK: Penelitian memiliki tujuan yaitu mengetahui apakah secara simultan dan parsial umur perusahaan, inflasi, dan suku bunga berpengaruh pada underpricing pada perusahaan propery dan real estate yang melakukan IPO di BEI periode 2012 - 2019. Sampel menggunakan kriteria yang telah ditentukan, terdapat 35 sampel perusahaan, dimana pengumpulan data dalam penelitian ini menggunakan dokumentasi, dan dianalisin dengan metode regresi. Berdasarkan penelitian diperoleh hasil umur perusahaan berpengaruh ke arah negatif terhadap underpricing, sedangkan inflasi dan suku bunga tidak memiliki pengaruh terhadap underpricing. Kesimpulannya secara simultan variabel umur perusahaan, inflasi dan suku bunga berpengaruh signifikan pada underpricing. Untuk secara parsial hanya umur perusahaan yang berpengaruh negatif pada underpricing.
\end{abstract}

Kata kunci: Underpricing, Umur perusahaan, Inflasi, dan Suku bunga.

\section{PENDAHULUAN}

Pasar modal menjadi tempat pembeli dan penjual untuk bertemu dan memiliki resiko untung dan rugi. Pasar modal menjadi tempat untuk perusahaan menjual saham atau obligasi dalam meningkatkan modal perusahaan (Hartono, 2009). Untuk memenuhi semakin luasnya permintaan, perusahaan menjual surat berharga atau saham ke masyarakat sebagai salah satu cara dalam mendapatkan modal. Perusahaan yang pertama kali melakukan go public atau menjual pertama kali saham ke masyarakat umum disebut dengan IPO. Di Indonesia perusahaan yang melakukan IPO berkembang pesat dari data perusahaan di www.e-bursa.com pada tahun 2016 perusahaan yang melakukan IPO sebanyak 15 perusahaan, tahun 2017 sebanyak 37 perusahaan melakukan IPO dan pada tahun 2018 sebanyak 58 perusahaan melakukan IPO. Berdasarkan data tersebut dapat dikatakan bahwa menjual saham menjadi alternative bagi perusahaan untuk memenuhi modal yang dibutuhkan. Imawati dan Adnyana (2017) mengatakan permintaan saham meningkat karena investor menilai saham mempunyai kemampuan untuk mengalami kenaikan. Kondisi underpricing tidak memberi keuntungan pada perusahaan karena pada kondisi underpricing perusahaan tidak memperoleh dana yang maksimal. Tetapi sebaliknya bagi investor kondisi underpricing memberi keuntungan. Investor akan memperoleh keuntungan atau tingkat pengembalian berupa capital gain saat membeli saham perdana dalam kondisi underpricing. Perusahaan yang melakukan IPO merupakan perusahaan yang berasal dari berbagai sektor. Salah satunya perusahaan sektor property dan real estate.

Menurut Lestari (2015) perusahaan dengan umur yang lama memiliki lebih banyak pengalamanyang dinilai dapat bertahan menghadapi berbagai rintangan dalam dunia bisnis, dan akan berpengaruh pada tingkat ketidakpastian perusahaan dimasa depan. Pernyataan ini didukung oleh penelitian Sohail dan Raheman (2009). Penelitian oleh Zhou dan Lao (2012) dimana hasil penelitian menujukkan adanya pengaruh negative antara umur perusahaan dan underpricing. 
Peningkatan tingkat inflasi dapat memberi pengaruh pada semua aspek terutama barang dan jasa dimana harga dari barang dan jasa akan menjadi meningkat saat inflasi tinggi terjadi. Naiknya biaya membuat pengeluaran untuk produksi juga meningkat yang menyebabkan daya beli masyarakat menjadi turun dalam penelitian menurut Rachmadhanto dan Raharja (2014) memiliki hasil yaitu inflasi tidak memiliki pengaruh terhadap underpricing.

Tingginya suku bunga akan membuat masyarakat yang akan berinvestas menjadi lebih tertarik untuk investasi melalui bank karena akan mendapat keuntungan yang besar. Rachmadhanto dan Raharja (2014) berpendapat suku bunga tidak mempunyai pengaruh terhadap underpricing.

Penelitian mempunyai tujuan yang pertama untuk dapat mengetahui apakah pengaruh umur perusahaan, inflasi dan suku bunga secara simultan terhadap underpricing, yang kedua untuk dapat mengetahui apakah umur perusahaan berpengaruh pada underpricing, yang ketiga untuk dapat mengetahui penaruh inflasi pada underpricing dan yang terakhir mengetahui apakah ada pengaruh suku bunga terhadap underpricing.

\section{TINJAUAN PUSTAKA}

Underpricing adalah gambaran dalam mengetahui adanya harga yang berbeda atau selisih pada harga di pasar perdana dan saham harga paada pasar sekunder di penutupan hari pertama Beatty R. (1989). Underpricing menjadi kejadian yang sangat umum dialami perusahaan yang melakukan IPO. Menurut Purba (2019) kejadian underpricing menjadikan perusahaan mengalami dilema, yaitu antara perusahaan yang menjual saham di pasar perdana dan investor yang menginvestasikan dana.Umur perusahaan merupakan berapa lama perusahaan untuk bisa bertahan, bersaing, dan dapat mengambil peluang bisnis dalam dunia ekonomi (Saptari, 2016). Menurut Lestari (2015) perusahaan dengan umur yang telah lama akan memiliki pengalaman yang lebih banyak sehingga dinilai dapat bertahan menghadapi berbagai rintangan dalam dunia bisnis, dan akan berpengaruh pada tingkat ketidakpastian perusahaan dimasa depan. Menurut Fahmi (2015) inflasi adalah kejadian yang terjadi saat harga barang dan jada mengalami kenaikan serta penurunan nilai mata uang. Menurut Rose (2009) inflation is " A rise in the average level of all prices of goods and services traded in the economy over any given period of time." Suku bunga dianggap bisa mempengaruhi emiten pada saat pemenuhan pendanaan dan memberi pengaruh pada investor saat akan melakukan investasi.

\section{Kerangka Konsep}

Variabel Independen

Variabel Dependen

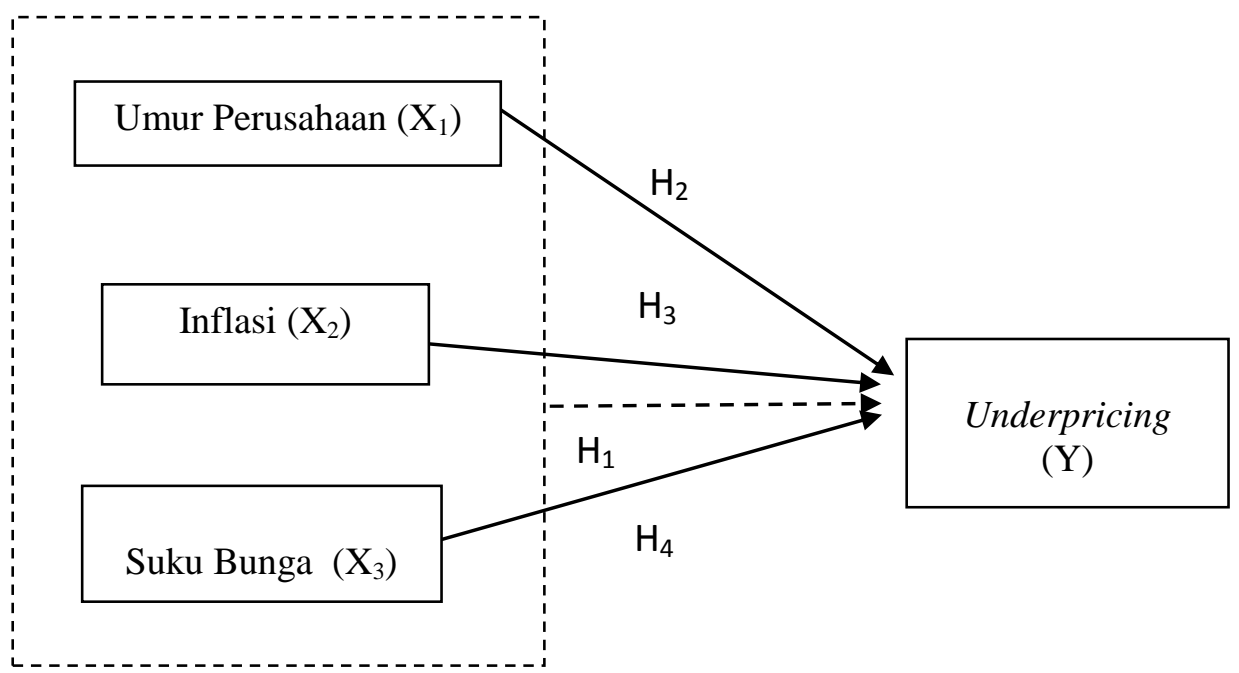




\section{METODE}

Kuantitatif digunakan dalam melakukan pendekatan dalam penelitian ini, dimana kuantitatif merupakan pendekatan dengan data berbentuk angka pada analisis statistic. Populasi yang diperoleh merupakan perusahaan propertindan real state yang terdaftar di BEI dan melakukan IPO pada periode 2012-2019 yaitu sebanyak 36 perusahaan. Sampel menggunakan purposive sampling dan analisis data menggunakan regresi linier berganda sehingga diperoleh sebanyak 35 sampel perusahaan setelah dilakukan eliminasi kriteria. Sifat data ini yaitu cross-section dimana data yang didapatkan dalam rentan waktu ditentukan tujuan menggambarkan suatu keadaan.Data dapat diperoleh dari situs resmi Bursa Efek Indonesia, Bank Indonesia, www.sahamok.com dan www.e-bursa.com.

\section{PEMBAHASAN}

Berdasarkan hasil yang diperoleh Umur Perusahaan, Inflasi, dan Suku Bunga secara simultan memiliki pengaruh positif terhadap Underpricing. Artinya secara bersamaan variabel bebas dalam penelitian ini memberikan pengaruh pada variabel terikat sehingga jika terjadi penurunan pada umur perusahaan, iflasi, dan suku bunga akan memberikan pengaruh pada underpricing di perusahaan property dan real estate yang melakukan IPO tahun 2012-2019. Berdasarkan hasil secara parsial Umur Perusahaan berpengaruh signifikan ke arah negative pada underpricing. Hal ini mengindikasikan semakin lama umur perusahaan maka tingkat underpricing akan menurun hasil penelitian ini sama dengan penelitian Manurung dan Nuzula (2019) menemukan bahwa variabel umur perusahaan secara parsial memiliki pengaruh negatif terhadap underpricing. Dapat disimpulkan bahwa umur perusahan memberikan pengaruh dengan arah negatif pada underpricing yang terjadi di perusahaan yang melakukan IPO karena umur perusahaan dianggap dapat meminimalisir resiko yang akan didapatkan kemudian hari tetapi umur perusahaan hanya salah satu faktor yang dapat mempengaruhi rendahnya tingkat underpricing terdapat beberapa faktor yang dapat mempengaruhi investor untuk dapat berinvestasi pada suatu perusahaan yaitu laporan keuangan. Untuk hasil inflasi ditemukan inflasi tidak berpengaruh terhadap underpricing dimana dapat dikatakan semakin rendah inflasi tidak akan mempengaruhi underpricing. Berdasarkan hasil deskripsi data tingkat inflasi memperoleh rata-rata $4.1 \%$ dimana menurut sifatnya nilai tersebut masih kurang dari $10 \%$ dan masuk pada inflasi dengan sifat yang rendah sehingga tidak memberikan efek yang merugikan.. Inflasi yang terjadi pada tahun 2012 - 2013 dapat dikatakan rendah mengakibatkan tidak memberikan dampak yang besar pada perusahaan property dan real estate, dan dalam jangka panjang tidak akan memberikan efek merugikan bagi investor. Hasil ini sesuuai dengan hasil penelitian Imawati dan Adnyana (2017) dimana variabel inflasi terhadap underpricing tidak berpengaruh signifikan. Dan terakhir untuk hasil suku bunga menunjukkan secara parsial suku bunga tidak berpengaruh terhadap underpricing pada perusahaan property dan real estate yang melakukannIPO di Bursa Efek Indonesia 2012 - 2019. Dapat diartikan bahwa setiap kenaikan ataupun penurunan suku bunga tidak dapat digeneralisasi berpengaruh pada underpricing. Pada deskripsi data suku bunga memiliki rata-rata sebesar 5.7\% dimana suku bunga masih terbilang normal sehingga dapat dikatakan meningkatnya suku bunga yang terjadi tidak menyumbangkan pengaruh terhadap underpricing pada perusahaan property dan real Estate yang melakukan IPO.

\section{KESIMPULAN}

1. Umur perusahaan, inflasi, dan suku bunga secara simultan berpengaruh terhadap underpricing perusahaan property dan real estate yang melakukan IPO di Bursa Efek Indonesia tahun 2012 - 2019,

2. Umur perusahaan memiliki pengaruh terhadap underpricing pada perusahaan yang melakukann IPO, dimana semakin besar nilai umur perusahaan maka akan mengurangi tingkat underpricing yang terjadi,

3. Inflasi tidak mempunyai pengaruh pada underpricing dimana semakin tinggi nilai Inflasi maka tidak akan meningkatkan underpricing,

4. Suku bunga tidak memliki pengaruh pada underpricing perusahaan yang melakukan IPO, dapat dikatakan semakin kecil nilai suku bunga maka akan tidak akan mengurangi underpricing. 


\section{DAFTAR PUSTAKA}

Aini, Shoviyah Nur. 2013. Faktor-faktor yang mempengaruhi underpricing saham pada perusahaan IPO di BEI Periode 2007-2011. Jurnal Ilmiah Manajemen.Vol 1(1)

Astuti, Asih dan Syahyunan. 2013. Pengaruh Variabel Keuangan dan Non Keuangan Terhadap Underpricing pada Saham Perusahaan yang Melakukan IPO di BEI. Skripsi tidak diterbitkan. Sumatera Utara: FE USU

Efni Yulia. 2009. Pengaruh Suku Bunga Deposito SBI, Kurs, Inflasi, Terhadap Harga Saham Perusahaan Real Estate dan Property di BEI. Jurnal Ekonomi. Vol 17(1):2

Hardi, Hasfin. 2009. Analisis dan Pengaruh Variabel Ekonomi Makro Terhadap Penetapan Harga Saham Perdana di Bursa Efek Jakarta. Jurnal Keuangan dan Bisnis. Vol 1(1)

Hartono, Jogiyanto. 2009. Teori Portofolio dan Analisis Investasi. yogyakarta: BPFE-Yogyakarta

Imawati, Adnyana I Made. 2017. Pengaruh Faktor-faktor Mikro dan Makro Ekonomi Terhadap Tingkat Underpricing Pada Saat IPO.Jurnal Ilmu Manajemen. 13 (2): 73

Lestari, A.H. 2015. Analisis Faktor-Faktor Yang Mempengaruhi Underpricing Saham Pada Penawaran Umum Perdana Di BEI Periode 2012-2014 (Studi Pada Perusahaan Yang Melaksanakan IPO Di Bursa Efek Indonesia Periode 2012-2014). Jurnal Administrasi Bisnis Universitas Brawijaya, 25(1): 19

Manurung, Aprilia dan Nuzula Nila. 2019. Pengaruh Variabel Non Keuangan Terhadap Underpricing Pada Saat Initial Public Offering (IPO) (Studi Pada Perusahaan Yang Listing Di Bursa Efek Indonesia Periode 2015-2018). Jurnal Administrasi Bisnis Universitas Brawijaya 69 (1): 64

Nurazizah dan Majidah. 2019. Analisis Faktor-faktor yang Mempengaruhi Tingkat Underpricing Pada Saat IPO di BEI. Jurnal Ilmiah MEA. Vol 3(3): 157-165

Rachmadhanto, David dan Raharja. 2014. Analisis Pengaruh Faktor Fundamental Perusahaan dan Kondisi Ekonomi Makro Terhadap Tingkat Underpricing saat Penawaran Umum Perdana. Jurnal Akuntansi. Vol 3(4): 3

Rose, Peter S. dan Milton H. Marquis. 2009. Money and Capital Market, International Edition, McGraw Hill. United States of America

Sharma and Seraphim. 2010. The Relationship Between IPO Underpricing Phenomenon \& The Underwriter's Reputation. The Economic Jurnal. Vol 38.

Sohail Khalid, Muhamad; Raheman, Abdul. 2009. Determinant Of Underpricing of IPOs Regarding Financial and Non Financial Firms in Pakistan. European Journal of Economics, Finance and Administrative Sciences. ISSN 1450-2887 Issue 15

Sugiyono. 2015. Metode Penelitian Pendidikan Pendekatan Kuantitatif, Kualitatif Dan R\&D. Bandung: Alfabeta

Zhou, J and Lao, L. 2012. Analysis of influencing factors of ipo underpricing in ChiNext. Shanghai Education Committee Research and Innovation Project, 33: 846851. 